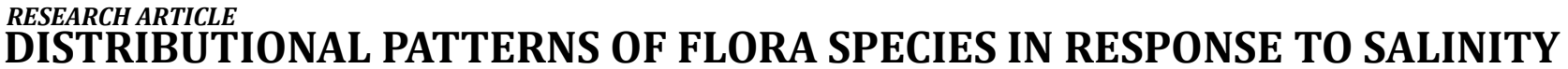 GRADIENTS IN A PALUSTRINE WETLAND
}

\author{
Ogbemudia $\mathrm{FO}^{1}$, Ita $\mathrm{RE}^{2 *}$ and Kekere $\mathrm{O}^{3}$ \\ ${ }^{1}$ Department of Botany and Ecological Studies, University of Uyo, Nigeria \\ ${ }^{2}$ Department of Biological Sciences, Ritman University, Ikot Ekpene, Nigeria \\ ${ }^{3}$ Department of Plant Science and Biotechnology, Adekunle Ajasin University, Akungba Akoko, Nigeria \\ *Corresponding Author E-mail: alwaizfwesh247@yahoo.com
}

This is an open access article distributed under the Creative Commons Attribution License, which permits unrestricted use, distribution, and reproduction in any medium, provided the original work is properly cited.

\section{ARTICLE DETAILS}

\section{Article History:}

Received 03 August 2019 Accepted 10 September 2019 Available online 17 September 2019

\section{ABSTRACT}

This study investigated the distributional patterns of species in response to salinity gradients. The vegetation was systematically sampled using a quadrat of $50 \times 10 \mathrm{~m}$. Vegetation variables were measured. At depths of $0-15$ and $15-30 \mathrm{~cm}$, sediment samples were dug and analyzed using standard methods. Fourteen species were encountered. Rhizophora mangle and Mytragyna ciliata had highest and least density values of $6664 \pm 687.16$ and $3.00 \pm 0.42$ st/ha. The most frequent species were Rhizophora mangle and Nypa fruticans (100\%). Rhizophora mangle and Mytragyna were tallest $(12.45 \pm 1.20 \mathrm{~m})$ and shortest species $(3.11 \pm 0.24 \mathrm{~m})$. Elaeis guineensis and Alchornea cordifolia had the largest $\left(1.79 \pm 0.05 \mathrm{~m}^{2} / \mathrm{ha}\right)$ and least $\left(0.008 \pm 0.0002 \mathrm{~m}^{2} / \mathrm{ha}\right)$ basal area values. Highest crown cover value was recorded by Rhizophora mangle $(9.14 \pm 0.08 \mathrm{~m} 2 / \mathrm{ha})$ while by Alchornea cordifolia had the least value $(0.04 \pm 0.001$ $\mathrm{m}^{2} / \mathrm{ha}$ ). Gradient analysis revealed that Ipomoea involucrata, Paspalum vaginatum, Dracaena mannii, Piptadeniastrum africanum, Elaeis guineensis, Staudtia stipitata, Alchornea cordifolia, Terminalia superba and Mytragyna ciliata belonged to ecological group 1 with ecological optima of 8.14, respectively. Acrostichum aureum (ecological optimum of 29.32), Avicennia africana (ecological optima of 19.56 and 30.12) and Phoenix reclinata (ecological optima of 8.14 and 29.32) belonged to ecological group 4 while Nypa fruticans (ecological optima of 8.14 and 29.32) and Rhizophora mangle (ecological optima of 19.56 and 30.12 ) belonged to ecological group 0 . This study provides information on species adaptation and performance in relation to environmental stress and will form the basis for the future and effective management of this ecosystems.

\section{KEYWORDS}

Salinity, Palustrine wetland, Mangrove, ecological amplitude, gradient analysis. best at salinity level of $15 \%$. In consonance to this, [3] reported that Sonneratia alba perform best between salinity range of $2 \%$ and $18 \%$ while its associate, Sonneratia lanceolata can only withstand a $2 \%$ salinity level. [4] also reported that Avicennia marina due to its high tolerance to salinity inhabit a wide range of intertidal habitats. [5] who studied the growth and performance of seedlings of seven species in response to two contrasting salinity regimes, low (i.e., 3-5) and medium (i.e., 25-27) of true mangroves of Sri Lanka observed that interaction between species and salinity varied among species. These variations in terms of tolerance to salinity have however resulted in floristic dynamics in this ecosystem. Furthermore, the intrinsic abilities of these species to survive harsh environmental conditions (wind action, tidal flushing and salinity) makes this ecosystem very critical for conservation.

Despite this dynamism among species in mangroves, the quantitative effects of abiotic factors, biotic interactions and performance of species are still far from being incorporated into ecological theory. Akwa Ibom is one of the states in the Niger Delta blessed with rich patches of wetland ecosystems of diverse types (fresh water and mangrove wetlands). Most of the species found in these ecosystems are facing serious threats such as salinity stress, intense anthropogenic like lumbering and deforestation. In recent years, studies on wetlands in this region have bordered mainly on freshwater types with fewer scientific literatures on the mangrove types. Also, the little information available on mangrove wetlands are focally on community structure of the forest without reference to the distributional patterns, performance and adaptation of each mangrove species to complex environmental factors such as salinity. Due to the dearth in literature in this regard, this paper seeks to investigate the intrinsic performance and distribution of species in mangroves in order to delineate their respective niche preference and adaptation to salinity gradients. 


\section{MATERIALS AND METHOD}

\subsection{Study Area}

This study was undertaken in a mangrove swamp of Okorombokho community in Eastern Obolo Local Government Area of Akwa Ibom State (Figure 1). The mangrove is located in the Niger Delta fringe between Imo and Qua Iboe Rivers estuaries and lies between latitudes $4^{\circ} 33^{\prime}$ and $4^{\circ} 50^{\prime}$ $\mathrm{N}$ and longitudes $7^{\circ} 45^{\prime}$ and $7^{\circ} 55^{\prime} \mathrm{E}$ with an altitude of about $650 \mathrm{~m}$ above sea level. The climate of the area is tropical with distinct rainy (April to October) and dry seasons (October to May) with a high annual rainfall averaging about $2500 \mathrm{~mm}$ [6]. The area is characterized by an extensive mangrove swamp with inter-tidal mud flats influenced by the semidiurnal tidal regime of the estuary. Fishing and farming are the main economic activities in this study area. Oil palm (Elaeis guineensis) and coconut palm (Cocus nucifera) are also widely distributed in the surrounding villages. The area is also an oil-producing area with several oil exploration wells.

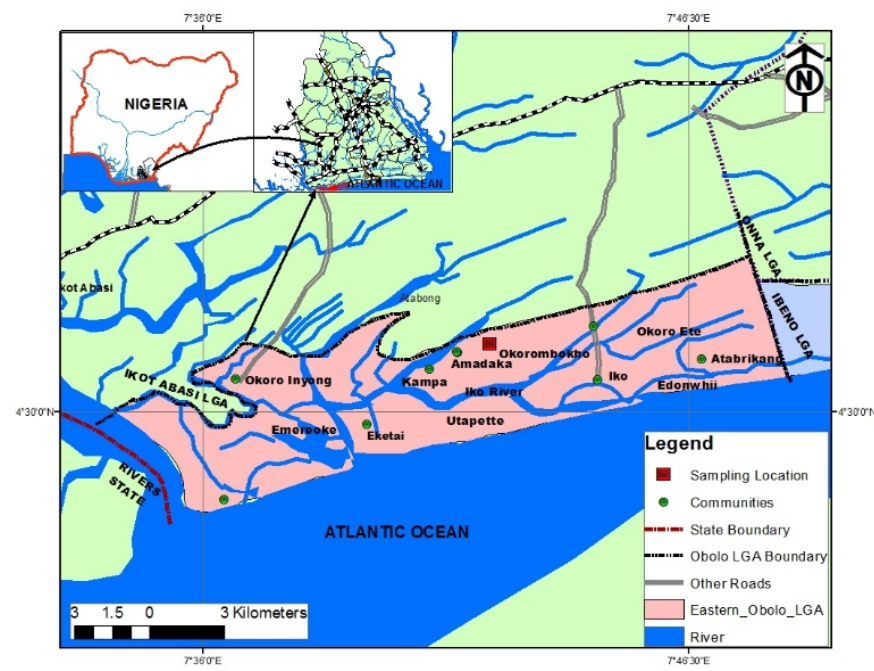

Figure 1: Map of the study area

\subsection{Vegetation and Soil Sampling}

In this study, the vegetation was sampled systematically using a quadrat of $50 \times 10 \mathrm{~m}$. The measured vegetation parameters were frequency, height, density, basal area, and crown cover. Using a soil corer in each of the quadrats, sediment samples were obtained at two depths; $0-15 \mathrm{~cm}$ and $15-$ $30 \mathrm{~cm}$. The soil samples were collected from seven (7) different stations. Stations I to VII were located at distances of $50 \mathrm{~m}, 500 \mathrm{~m}, 650 \mathrm{~m}, 800 \mathrm{~m}$, $1100 \mathrm{~m}, 1600 \mathrm{~m}$ and $2100 \mathrm{~m}$ from the coast. These were stored in labeled Ziploc bags and taken to the laboratory for physicochemical analyses.

\subsection{Quantitative Determination of Vegetation Parameters}

\subsubsection{Height}

The heights of the woody plant species were measured using a Haga altimeter. For each of the woody plant height, the Haga altimeter was thus used: the reading was taken $15 \mathrm{~m}$ away from the base of the woody plant from where the crown was sighted through the eye piece of the altimeter and the upper reading taken. The base of the woody plant was similarly sited and the lower altimeter readings taken. The height of each species was calculated using the relation:

Height $(\mathrm{m})=$ Algebraic sum of the reading of the top and bottom of each plant $\times$ horizontal distance from observer to each species divided by scale factor used on the altimeter.

\subsubsection{Basal Area}

This was calculated using the formula:

Basal Area $=\frac{\mathrm{C}^{2}}{4 \pi}$

Where $4 \pi=4 \times 3.142=12.568$

$\mathrm{C}=$ girth size of the species at breast height

\subsubsection{Crown Cover}

The crown cover of woody plant species was determined by the crown cover diameter method [7].

\subsubsection{Frequency}

The frequency of each species occurrence was calculated thus:

Frequency $=\frac{\text { Number of occupied quadrat for a species }}{\text { Total number of quadrats thrown }} \times 100$

\subsubsection{Density}

The density of individual species was measured using the methods as outlined by [8].

\subsection{Analysis of Soil Samples}

The soil samples were air-dried, ground using a mortar and pestle and passed through a $2 \mathrm{~mm}$ sieve before the determination of the soil physicochemical variables. The salinity of the soil was determined from electrical conductivity in soil-water samples by means of a conductivity meter.

\subsection{Statistical Data Analysis}

Mean and standard errors of triplicates were computed using Statistical Package for Social Sciences (SPSS 20.0). Direct gradient analysis using the method of [9] was carried out to relate species distribution along salinity gradient. From the result obtained for the gradient analysis, species were categorized into the following 6 groups as proposed by [9]:

- Species which dominate and occur almost exclusively under the most nearly limiting conditions of the factor.

- Species of similar occurrence but with wider amplitude than those of group 1.

- Species which are especially frequent near the mid-point along the factor gradient.

- Species which dominate on the gradient where the factor being considered is in plentiful supply.

- Species which occur almost exclusively at the highest values of the factor being considered.

- Species which are indifferent to the factor and have a very wide amplitude.

\section{RESULTS}

\subsection{Floristic Composition of the Mangrove Swamp}

Table 1 shows the mean floristic compendium of the mangrove. A total of 14 plant species were found in this mangrove belonging to 12 families. With regards to the density of species, Rhizophora mangle dominated with mean value of (6664 $\pm 687.16 \mathrm{st} / \mathrm{ha}$ ) while Mytragyna ciliata had the least density value $(3.00 \pm 0.42 \mathrm{st} / \mathrm{ha})$. Rhizophora mangle and Nypa fruticans had the highest frequency values $(100 \%)$ while the least values were associated with species such as Ipomoea involucrata (14.29\%), Staudtia stipitata (14.29\%), Piptadeniastrum africanum (14.29\%), Alchornea cordifolia (14.29\%), Terminalia superba (14.29\%) and Mytragyna ciliata (14.29 \%). The tallest species was Rhizophora mangle $(12.45 \pm 1.20 \mathrm{~m})$ while the shortest species was Mytragyna ciliata $(3.11 \pm 0.24 \mathrm{~m})$. Elaeis guineensis and Alchornea cordifolia had the largest $\left(1.79 \pm 0.05 \mathrm{~m}^{2} / \mathrm{ha}\right)$ and least $\left(0.008 \pm 0.0002 \mathrm{~m}^{2} / \mathrm{ha}\right)$ basal area values, respectively. Highest crown cover value was recorded by Rhizophora mangle $\left(9.14 \pm 0.08 \mathrm{~m}^{2} / \mathrm{ha}\right)$ while the least was recorded by Alchornea cordifolia $\left(0.04 \pm 0.001 \mathrm{~m}^{2} / \mathrm{ha}\right)$.

Table 2 shows the individual density of species occurring at varying distances from the coast spatially (I-VII). Nypa fructicans and Rhizophora mangle occurred in all the seven sampled stations, Paspalum vaginatum occurred in four stations (IV, V, VI and VII), Phoenix reclinata occurred in three of the stations (Stations V, VI and VII), Elaeis guineensis and Dracaena mannii occurred in two stations (VI and VII) while species such as Ipomoea involucrata Staudtia stipitata, Piptadeniastrum africanum, Alchornea cordifolia, Terminalia superba and Mytragyna ciliata occurred in only one station (VII). 
Table 1: Mean ( \pm S.E) Floristic Composition of the Wetland

\begin{tabular}{|c|c|c|c|c|c|c|}
\hline Plant Species & Family & $\begin{array}{l}\text { Density } \\
\text { (Stems/ha) }\end{array}$ & $\begin{array}{l}\text { Frequency } \\
(\%)\end{array}$ & Height (m) & $\begin{array}{l}\text { Basal Area } \\
\left(\mathrm{m}^{2} / \mathrm{ha}\right)\end{array}$ & $\begin{array}{l}\text { Crown Cover } \\
\left(\mathrm{m}^{2} / \mathrm{ha}\right)\end{array}$ \\
\hline Nypa fruticans Wurmb. & Arecaceae & $3600 \pm 109.03$ & 100 & $4.51 \pm 0.58$ & $0.21 \pm 0.05$ & $3.23 \pm 0.14$ \\
\hline Rhizophora mangle $\mathrm{L}$. & Rhizophoraceae & $6664 \pm 687.16$ & 100 & $12.45 \pm 1.20$ & $0.92 \pm 0.05$ & $9.14 \pm 0.08$ \\
\hline Acrostichum aureus L. & Pteridaceae & $2148.6 \pm 303.05$ & 71.43 & $4.12 \pm 0.54$ & - & - \\
\hline Avicennia africana P. Beau & Avicenniaceae & $3143.14 \pm 436.53$ & 85.71 & $5.02 \pm 0.85$ & $0.18 \pm 0.02$ & $0.48 \pm 0.001$ \\
\hline Ipomoea involucrata P. Beauv. & Convolucaceae & $78.00 \pm 10.36$ & 14.29 & - & - & - \\
\hline Paspalum vaginatum $\mathrm{Sw}$. & Poaceae & $1693.75 \pm 89.93$ & 57.14 & - & - & - \\
\hline Elaeis guineensis Jacq. & Arecaceae & $38.50 \pm 6.50$ & 14.29 & $8.50 \pm 0.5$ & $1.79 \pm 0.05$ & $4.27 \pm 0.58$ \\
\hline Staudtia stipitata Warb. & Myristicaceae & $32.00 \pm 6.02$ & 14.29 & $7.20 \pm 0.99$ & $0.8 \pm 0.04$ & $2.69 \pm 0.41$ \\
\hline Dracaena mannii (Willd.) Link & & $18.50 \pm 6.50$ & 28.57 & $10.11 \pm 0.83$ & $0.11 \pm 0.04$ & $5.07 \pm 0.76$ \\
\hline $\begin{array}{l}\text { Piptadeniastrum africanum (Hook } \\
\text { f.) Brenan. }\end{array}$ & Fabaceae & $15.00 \pm 5.98$ & 14.29 & $8.05 \pm 0.72$ & $0.42 \pm 0.03$ & $6.12 \pm 0.05$ \\
\hline $\begin{array}{l}\text { Alchornea cordifolia (Schum, \& } \\
\text { Thonn.) Mull. Arg }\end{array}$ & Euphorbiaceae & $60.00 \pm 13.21$ & 14.29 & $3.33 \pm 0.88$ & $0.008 \pm 0.000$ & $0.04 \pm 0.001$ \\
\hline Terminalia superba Engl. \& Diels & Combretaceae & $9.00 \pm 2.35$ & 14.29 & $8.02 \pm 1.05$ & $1.05 \pm 0.15$ & $5.65 \pm 0.85$ \\
\hline $\begin{array}{l}\text { Mytragyna ciliata (Aubrev and } \\
\text { Pellegr) }\end{array}$ & Rubiaceae & $3.00 \pm 0.42$ & 14.29 & $3.11 \pm 0.24$ & $0.82 \pm 0.04$ & $2.10 \pm 0.26$ \\
\hline Phoenix reclinata Jacq & Arecaceae & $48.00 \pm 3.79$ & 42.86 & - & - & - \\
\hline
\end{tabular}

Table 2: Density (stems/ha) of Plant species at different stations of the Wetland

\begin{tabular}{|c|c|c|c|c|c|c|c|}
\hline \multicolumn{8}{|c|}{ Stations (Distance from the coast $\mathrm{m}$ ) } \\
\hline Plant Species & $\begin{array}{l}\text { I } \\
(50 \mathrm{~m})\end{array}$ & II (500 m) & III $(650 \mathrm{~m})$ & $\begin{array}{l}\text { IV } \\
(800 \mathrm{~m})\end{array}$ & $\mathrm{V}(1100 \mathrm{~m})$ & VI (1600 m) & VII $(2100 \mathrm{~m})$ \\
\hline Nypa fruticans & 6500 & 6240 & 6400 & 4100 & 1150 & 560 & 250 \\
\hline Rhizophora mangle & 8650 & 8250 & 8365 & 6200 & 6362 & 4321 & 4500 \\
\hline Acrostichum aureum & 1650 & 2864 & 2915 & 1604 & 1710 & - & - \\
\hline Avicennia africana & 5360 & 4124 & 4254 & 3136 & 3081 & 2047 & - \\
\hline Ipomoea involucrata & - & - & - & - & - & - & 78 \\
\hline Paspalum vaginatum & - & - & - & 1462 & 1856 & 1643 & 1814 \\
\hline Elaeis guineensis & - & - & - & - & - & 32 & 45 \\
\hline Staudtia stipitata & - & - & - & - & - & - & 32 \\
\hline Dracaena mannii & - & - & - & - & - & 12 & 25 \\
\hline Piptadeniastrum africanum & - & - & - & - & - & - & 15 \\
\hline Alchornea cordifolia & - & - & - & - & - & - & 60 \\
\hline Terminalia superba & - & - & - & - & - & - & 9 \\
\hline Mytragyna ciliata & - & - & - & - & - & - & 3 \\
\hline Phoenix reclinata & - & - & - & - & 54 & 41 & 49 \\
\hline
\end{tabular}

\subsection{Spatial Variations of Salinity in the Estuary}

Table 3 shows the mean spatial variations of salinity in the mangrove. Salinity values ranged between $8.14 \pm 1.00 \mathrm{ppt}$ (station VII) and $30.12 \pm 4.36 \mathrm{ppt}$ (station I). Graphically, this is well represented in Figure 2.

Table 3: Mean $( \pm$ S.E) Spatial Variations of Salinity in the Estuary

\begin{tabular}{|c|c|c|c|c|c|c|c|}
\hline \multirow[b]{2}{*}{ Parameter } & \multicolumn{7}{|l|}{ Stations } \\
\hline & I & II & III & IV & V & VI & VII \\
\hline Salinity (ppt) & $30.12 \pm 4.36$ & $27.45 \pm 4.01$ & $29.32 \pm 4.15$ & $19.56 \pm 2.47$ & $19.10 \pm 2.12$ & $12.02 \pm 1.86$ & $8.14 \pm 1.00$ \\
\hline
\end{tabular}

\section{$\pm=$ Standard error}

\subsection{Species Distribution and Ecological Group Classification}

The modalities of the species on soil salinity gradients are presented in Figures 2 - 15. Species such as Ipomoea involucrata, Paspalum vaginatum, Dracaena mannii, Piptadeniastrum africanum, Elaeis guineensis, Staudtia stipitata, Alchornea cordifolia, Terminalia superba and Mytragyna ciliata belonged to ecological group 1 with ecological optimum of 8.14, respectively. Acrostichum aureum (ecological optimum of 29.32), Avicennia africana (ecological optima of 19.56 and 30.12) and Phoenix reclinata (ecological optima of 8.14 and 29.32) belonged to ecological group 4 while Nypa fruticans (ecological optima of 8.14 and 29.32) and Rhizophora mangle (ecological optima of 19.56 and 30.12) belonged to ecological group 0 .

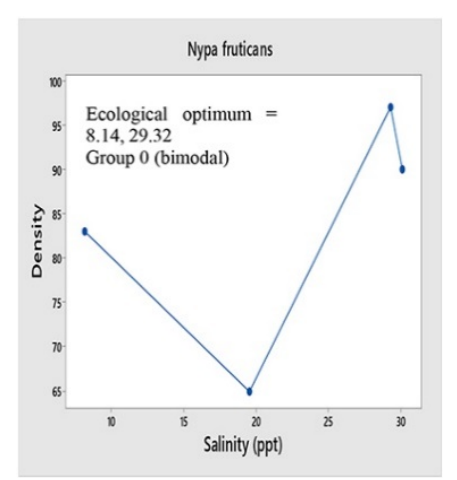

Figure 2: Performance of Nypa fruticans along salinity gradient 


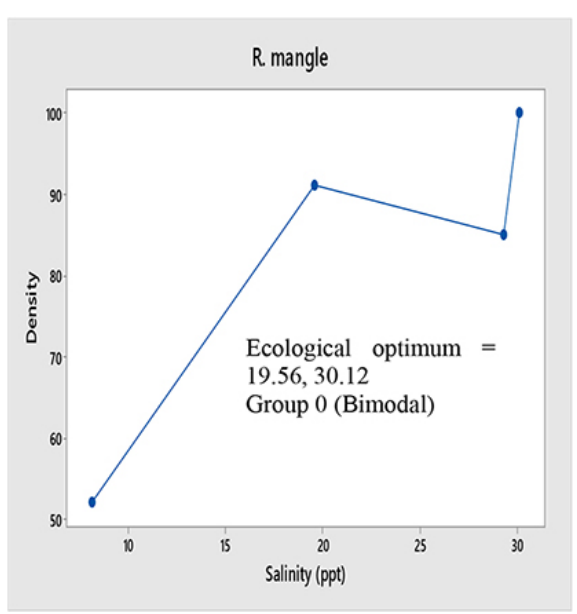

Figure 3: Performance of Rhizophora mangle along salinity gradient

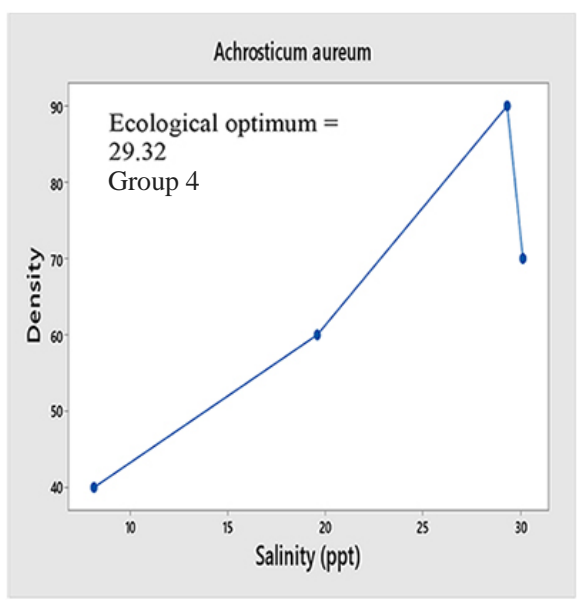

Figure 4: Performance of Acrostichum aureum along salinity gradient

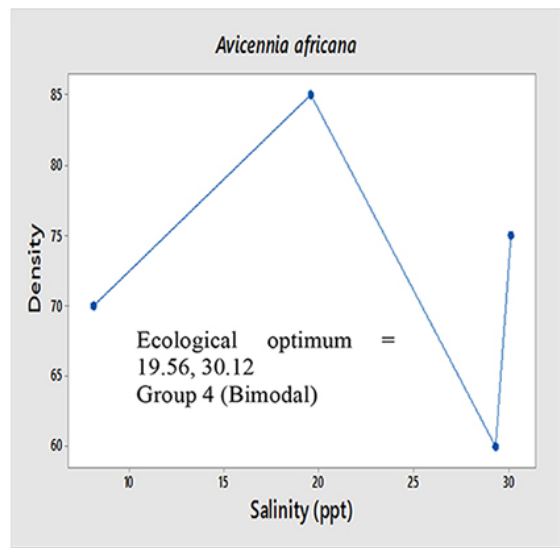

Figure 5: Performance of Avicennia Africana along salinity gradient

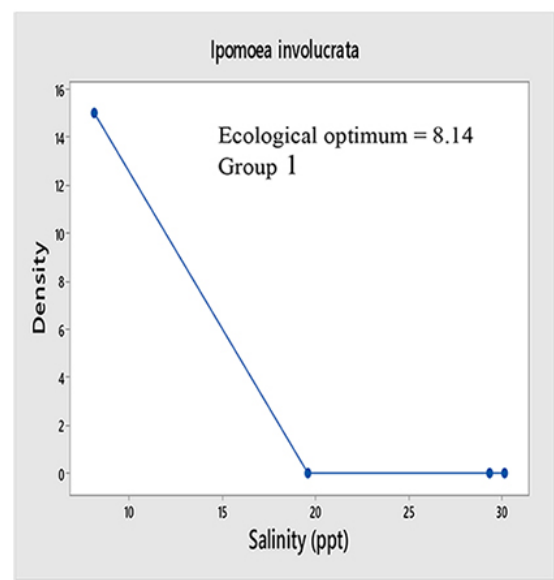

Figure 6: Performance of Ipomoea involucrata along salinity gradient

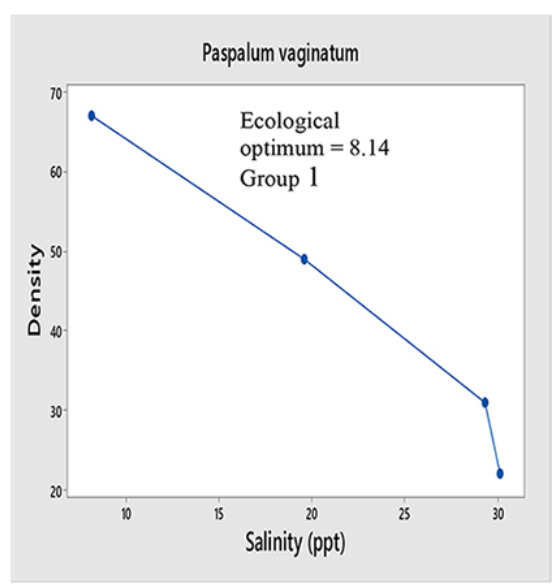

Figure 7: Performance of Paspalum vaginatum along salinity gradient

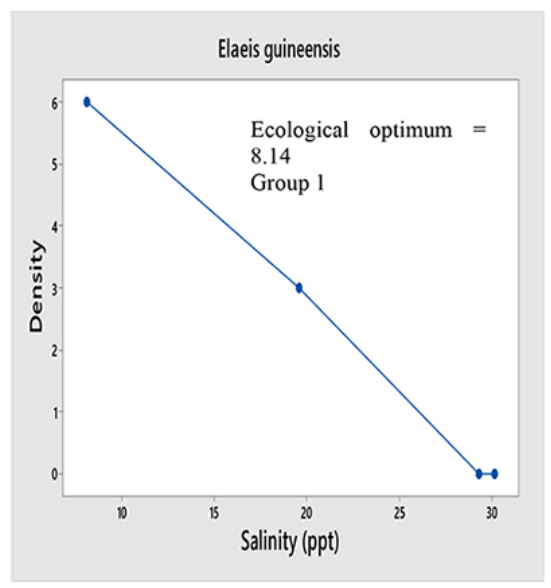

Figure 8: Performance of Elaeis guineensis along salinity gradient

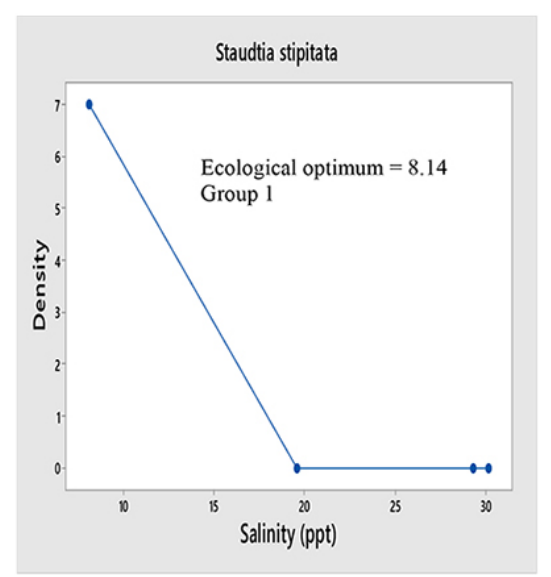

Figure 9: Performance of Staudtia stipitata along salinity gradient



Figure 10: Performance of Dracaena mannii along salinity 


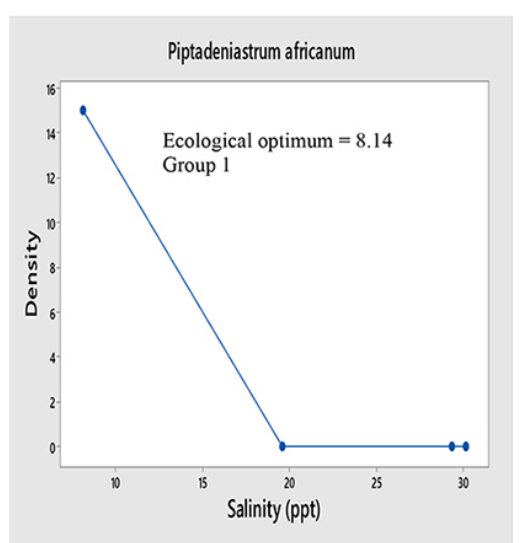

Figure 11: Performance of Piptadeniastrum africanum along salinity gradient

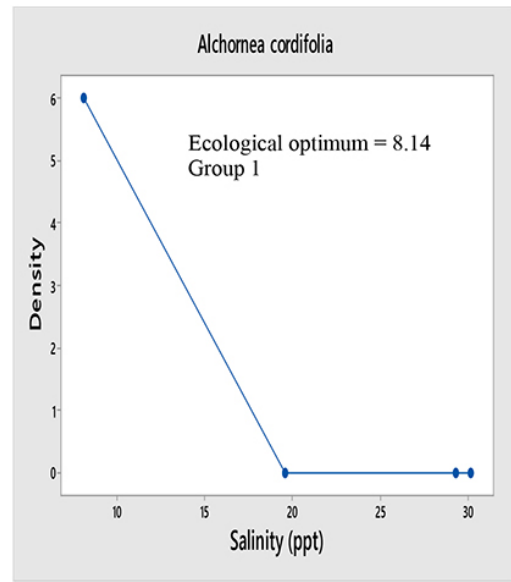

Figure 12: Performance of Alchornea cordifolia along salinity gradient



Figure 13: Performance of Terminalia superba along salinity gradient

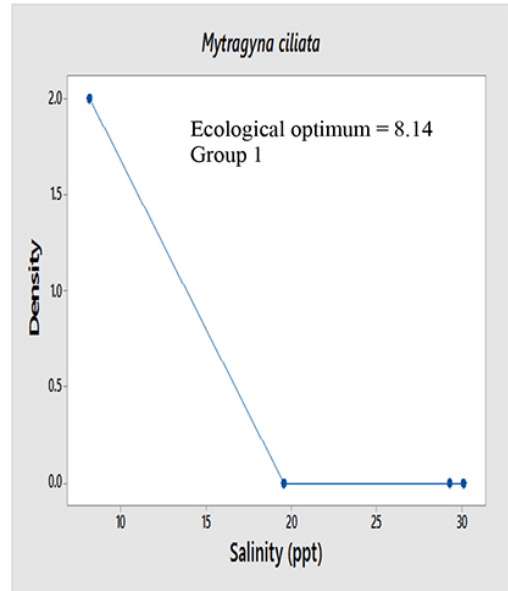

Figure 14: Performance of Mytragyna ciliate along salinity gradient

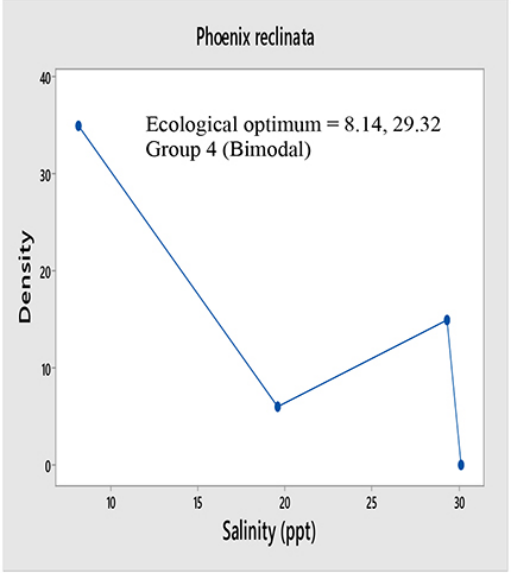

Figure 15: Performance of Phoenix reclinata along salinity gradient

\section{DISCUSSION}

This ecosystem revealed a mixed compendium of core mangrove and strand species occupying different ecological niches. A total number of 14 flora species were encountered in this mangrove. This number is high when compared to the 10 species reported by [10] while working in Sundarbans mangrove swamps in India. However, this value is pretty low in comparison with the 15 species reported by [11] in mangrove swamps of Southeastern Nigeria. These variations in species composition may be attributed to various factors ranging from the inherent abilities of species to adapt to prevailing environmental conditions (tidal inundations and salinity regimes) in mangrove, anthropogenic pressures and selective exploitation of species with high economic values. Variations were observed in the floristic attributes of the mangroves ranging from density, frequency, height, basal area and crown cover. While the obligate mangroves were distinct with high density values, their strand associes (non mangroves) had low density values. These variations in density values may be allied to the fact that these species had different niche tolerances to salinity regimes. This may imply that the obligate mangrove species had a better adaptability potential to salinity than the nonmangrove species. Similar trend was reported by [11] and [12]. Notably, the dominance or highest density value associated with Rhizophora mangle should not be overlooked but may rather confirm that these species is a true native and pioneer member of this estuary. The varying frequency values of species in the mangrove may also point to the different tolerant limits and levels of competition for environmental resources among taxa. The highest frequency values $(100 \%)$ observed in Nypa fruticans and Rhizophora mangle in this study may not be unrelated to the fact that these species possessed wide ecological amplitudes as well as good reproductive abilities and strategies which might have compensated effectively for their massive proliferation and distribution in saline habitats. Rhizophora mangle is well known for its viviparous mode of reproduction (germination of seed while still being attached to the mother plant). This reproductive strategy tends to increase the chances of a successful establishment in an unpredictable environment where germination of seeds would typically be inhibited. This agrees with the reports of [13]. The dispersal of seedlings of Nypa fruticans on the other hand is facilitated by tidal inundation which transports and deposits them on mudflats in the mangrove. It is worthy of note that during this transit, the seeds remain viable for a longer period germinating at the same time until it gets to a favourable substrate for its establishment. Nypa also has an additional advantage for rapid colonization through the formation of rhizomes. This further confirms their presence in all the stations at various distances from the coast. Invariably this can be explained to mean that these species are capable of withstanding fluctuations in the environmental conditions (salinity). The low frequency values of species may suggest their narrow ecological amplitudes in the mangal. This may further imply that these species were found where the environmental conditions were relatively stable. The variations noted for height, basal area and crown cover may insinuate the age differences evidenced among species. These may also be a reflection of their growth behaviour in the ecosystem.

The spatial variation in salinity in the ecosystem revealed that salinity concentration increased with proximity to the coast and decreased with distances away from the coast. This is not unprecedented as it is established that salinity levels tend to increase as one moves away from fresh water sources towards the ocean [14].

Gradient analysis as adopted in this study is a research method for studying the spatial patterns of occurrence or arrangement of species in 
response to environmental factors. According to [9], it seeks to understand the structure and variation of the vegetation of a landscape in terms of gradients in space of variables on three levels namely; environmental factors, species populations and characteristics of communities. This is evidenced in this study as the gradient analysis performed on plant species was based on salinity. From the result, variability in plant species occurrence with regards to salinity gradients were observed spatially.

The modalities and response of plant species on soil salinity gradient as shown in Figures 1 - 14 related information on the ecological amplitudes and optima for each mangrove species. Ipomoea involucrata, Paspalum vaginatum, Dracaena mannii, Piptadeniastrum africanum, Elaeis guineensis, Staudtia stipitata, Alchornea cordifolia, Terminalia superba and Mytragyna ciliata belonged to ecological group 1 with ecological optima of 8.14 each along salinity gradient. The placement of these species into ecological group 1 is not without environmental implications but rather show that species dominated and occurred exclusively at niches where least salinity values were recorded in the estuary. This may suggest that these species were sensitive to increasing salinity as they were not found in highly saline sites. Their inability to adapt favourably to saline conditions may expound that these species are non-mangrove species but rather are listed in the anthology of freshwater species.

Acrostichum aureum, Avicennia africana and Phoenix reclinata belonged to ecological group 4 because they dominated and flourished where the concentrations of salt appeared to be plentiful. While Acrostichum aureum was unimodal, Avicennia africana (19.56 and 30.12) and Phoenix reclinata (8.14 and 29.32) were bimodal in terms of ecological optima. The unimodal nature of Acrostichum aureum may suggest that this species had a specific salinity level required for its optimum performance. Similarly, the bimodal nature of Avicennia africana and Phoenix reclinata may not differ from the fact that these species have range of values they can adapt favourably to salinity in the ecosystem.

Nypa fruticans and Rhizophora mangle belonged to ecological group 0 since they were insensitive to salinity as an environmental factor. This implies that these species had the widest ecological amplitudes in this mangrove and are highly acclimatized to varying salinity levels. This also shows that these species are the most ecologically adaptive in this mangrove under the influence of salinity. The inclusion or classification of these species into ecological group 0 deviates from the findings of [11] where the scholar grouped this species into ecological groups 3 (Rhizophora mangle) and 4 (Nypa fruticans) in mangrove swamp in southeastern Nigeria. The scholar further reported Avicennia africana to be the species with the widest ecological magnitude. This variation may be attributed to the time and mangrove ecosystem selected for the study.

\section{CONCLUSION}

Salinity exerts profound effects on the distributional patterns of plant species in mangrove ecosystems. This study established that the distribution of the plant species in terms of density and frequency varied based on their levels of adaptability to salinity. The core mangroves were insensitive while the non-mangroves were sensitive to this environmental variable. The gradient analysis revealed that the mangrove species had different ecological amplitudes along the soil salinity gradient. Conclusively, this study provides information for understanding the adaptation of various plant species to harsh environmental conditions (salinity) thereby making this ecosystem critical for future conservation, restoration and sustainable management.

\section{REFERENCES}

[1] Cintron, G., Novelli, Y.S. 1984. Methods for studying mangrove structure, In: Snedaker, S. C.and Snedaker, J. G. (eds.) The mangrove ecosystem: research methods. United Nations Educational, Scientific and Cultural Organization, Paris, 91 -113.

[2] Kathiresan, K., Rajendran, N., Thangadurai, G. 1996. Growth of mangrove seedlings in the intertidal area of Vellar estuary, southeast coast of India. Indian J. Mar. Sci., 25, 240-243.

[3] Ball, M.C., Pidsley, S.M. 1998. Establishment of tropical mangrove seedings in relation to salinity. In: Proceedings of Workshop on Research and Management in Darwin Harbour, 123 - 124.

[4] Dahdouh-Guebas, F., Verneirt, M., Cannicci, S., Kario, J.G., Tack, J.F., Koedam, N. 2004. Human-impacted Mangroves in Gazi (Kenya): predicting future vegetation based on retrospective remote sensing, social surveys, and tree distribution. Marine Ecology Progress Series, 272, 77 - 79.

[5] Jayatissa, L.P., Wickramasinghe, W.A., Dahdouh-Guebas, F., Huxham, M. 2008. Interspecific variations in responses of mangrove seedlings to two contrasting salinities. International Review of Hydrobiology, 93(6), 700 710 .

[6] AKUTEC. 2005. Final Report for the Implementation of Akwa Ibom State University, 202.

[7] Muller-Dombois, D., Ellenberg, H. 1974. Aims and Methods of Vegetation Ecology. John Wiley, London, 98.

[8] Cochran, W.G. 1963. Sampling Techniques, 2nd. Edition. Wiley Eastern Limited, New Delhi. 413.

[9] Whittaker, R.H. 1967.Gradient Analysis of Vegetation. Biological Reviews, 49, 207 - 264

[10] Joshi, H., Ghose, M. 2003. Forest structure and species distribution along soil salinity and $\mathrm{pH}$ gradient in mangrove swamps of the Sundarbans. Tropical Ecology, 44(2), 197 - 206.

[11] Ukpong, I.E. 1991. The performance and distribution of species along soil salinity gradients of mangrove swamps in southeastern Nigeria Vegetation, 95, $63-70$.

[12] López-Hoffman, L., Anten, N.P.R., Martinez-Ramos, M., Ackerly, D.D. 2007. Salinity and light interactively affect neotropical mangrove seedlings at the leaf and whole plant levels. Oecologia, 150, 545 - 556

[13] Ball, M.C. 1988. Ecophysiology of Mangroves. Trees-Structure and Function, $2,129-142$.

[14] Ronald, L.O., Kathleen, M.R. 2006. Volunteer Estuary Monitoring Manual: A methods manual (2nd edition). The Ocean Conservancy, Washington D.C., 396. 